\title{
The Evolution of some Agroclimatic Indicators be- tween 2009 - 2013 in the Transylvanian Plain
}

\author{
Camelia-Liliana COSTE*, Teodor RUSU, Ileana BOGDAN, Adrian Ioan POP, Paula Ioana MORARU, Bogdan \\ Matei DUDA
}

Faculty of Agriculture, University of Agricultural Sciences and Veterinary Medicine Cluj-Napoca 3-5, Mănăştur Street, 400372, Cluj-Napoca, Romania;

* corresponding author: cameliacoste@yahoo.com

Bulletin USAMV series Agriculture 72(1)/2015

Print ISSN 1843-5246; Electronic ISSN 1843-5386

DOI 10.15835/buasvmcn-agr: 10688

\begin{abstract}
Transylvanian Plain (TP) with an area of 395,616 hectares is considered one of the most affected areas with the lowest capacity to adapt to existing climate change. In these conditions, the climate monitoring and implementation of measures to adapt to these changes are essential for sustainable development of agricultural technologies. Purpose of these paper is to analysis of data obtained in relation to the principles of soil conservation and adaptation to climate phenomena observed in monitoring agro-climatic factors. In this study we used data of temperature and humidity electronically recorded by eight HOBO microstations located in the Transylvanian Plain, which determine the rainfalls and temperature to a height of $1 \mathrm{~m}$, the soil temperature (at $10,30,50 \mathrm{~cm}$ depth in soil) and soil moisture (at $10 \mathrm{~cm}$ depth). In TP the multiannual average of temperature at $10 \mathrm{~cm}$ depth in soil recorded during $2009-2013$ is $11.22^{\circ} \mathrm{C}$, respectively $11.23^{\circ} \mathrm{C}$ at $50 \mathrm{~cm}$ depth in soil and the multiannual average of soil moisture recorded in the same period is $0.227 \mathrm{~m}^{3} / \mathrm{m}^{3}$. The multiannual average value of precipitation is 465.25 $\mathrm{mm}$. Results highlight the dynamic evolution of soil moisture and air temperature in Transylvanian Plain due to agro-climatic analysis of the indicators calculated for the period 2009-2013.
\end{abstract}

Keywords: climate monitoring, agroclimatic indicators, Transylvanian Plain.

\section{INTRODUCTION}

Climate warming is a phenomenon already revealed by the analysis of observational data for long periods of time (Busuioc et al., 2007). In the report of European Environment Agency (2012) it is on record that the effects of climate change in agriculture are reflected in changing areas of crop suitability and the phenology and plant vegetation period. Babinszky l. et al. (2011) believes that increasing the average daily temperature is a consequence shortening plant vegetation period.

For Romania, Busuioc et al. (2014) mentioned that were detect an increasing trends of extreme temperatures in all seasons, but regards extreme rainfall climatic signal is not as clear as for temperature extremes.
Depth of soil hydrological reserve can be considered one of the key parameters in modeling soil (Van Den Hurk et al.,2005). European Environmental Agency (2012) considers that there are no clear trends in soil water retention due to the lack of systematic data, but projections suggest significant reductions in soil moisture in the Mediterranean region. Several scientific results on climate changes were included in policies and strategies to adapt to climate change actions (Lereboullet et al., 2013)

Transylvanian Plain (TP) is considered one of the most affected areas with the lowest capacity to adapt to existing climate change. 
Under these conditions, the climate monitoring and implementation of measures to adapt to these changes are essential for sustainable development of agricultural technologies (Rusu et.al, 2012, 2013).

This paper aims to monitor climatic conditions (soil temperature, air temperature, precipitation) of TP and calculation agroclimatic indicators for the period 2009-2013.

\section{MATERIALS AND METHODS}

In the study we used data of temperature and humidity electronically recorded by eight microstations (HOBO-MAN-H21-002 type) located in the Transylvanian Plain, which allow storage of electronic data and viewing it through the HOBOware Pro Software Version 2.3.0., data witch after that was statistically analyzed and interpreted. To record rainfall stations were provided with rain gauges RG3-M type. Climatic elements monitoring stations were located in different areas with different pedoclimatic issues from TP.

Tab. 1. Location of station in Transylvanian Plain

\begin{tabular}{cccc}
\hline $\begin{array}{c}\text { Nr. } \\
\text { crt. }\end{array}$ & Station name & Latitude & $\begin{array}{c}\text { Elevation } \\
(\mathrm{m})\end{array}$ \\
\hline 5 & Taga (C) & 46.975769 & 316 \\
\hline 6 & Branistea (BN) & 47.17046 & 291 \\
\hline 4 & Dipsa (BN) & 46.966299 & 356 \\
\hline 7 & Zoreni (BN) & 46.893457 & 487 \\
\hline 3 & $\begin{array}{c}\text { Sillivasu de } \\
\text { Campie (BN) }\end{array}$ & 46.781705 & 463 \\
\hline 8 & $\begin{array}{c}\text { Filpișu Mare } \\
(M S)\end{array}$ & 46.746178 & 410 \\
\hline 2 & Band (MS) & 46.584881 & 318 \\
\hline 1 & Triteni (C) & 46.59116 & 342 \\
\hline MS = Mures County; Cf =Cluj County; BN=Bistrita-Nasaud County
\end{tabular}

TP stations are located at elevation between $316 \mathrm{~m}$ Țaga station and $487 \mathrm{~m}$ at Zoreni station, covering areas in the Cluj county (CJ), BistrițaNăsăud county (BN) and Mureș county (MS) wich are included in the geographical unit.(Tab. 1)

Data on soil temperature were recorded at 10 , 30 and $50 \mathrm{~cm}$ depth, air temperature and rainfall to a height of $1 \mathrm{~m}$, and soil moisture at $10 \mathrm{~cm}$ depth in soil. In terms of soil temperature, in this paper are presented the annual and multi-annual average values to $10 \mathrm{~cm}$ and $50 \mathrm{~cm}$ depths in soil.

\section{RESULTS AND DISCUSSIONS}

In TP the multiannual average of temperature at $10 \mathrm{~cm}$ depth in soil recorded during 2009-2013 is $11.22^{\circ} \mathrm{C}$, respectively $11.23^{\circ} \mathrm{C}$ at $50 \mathrm{~cm}$ depth in soil and the multiannual average of soil moisture recorded in the same period is $0.227 \mathrm{~m}^{3} / \mathrm{m}^{3}$.

Temperature range of multiannual average at $10 \mathrm{~cm}$ depth in soil is between $10.47^{\circ} \mathrm{C}$ (at Triteni station) and $12.92^{\circ} \mathrm{C}$ (at Filpișu Mare station) and the annual average temperature at $50 \mathrm{~cm}$ depth in the soil was between $10.63^{\circ} \mathrm{C}$ (Zoreni station) and $12.80^{\circ} \mathrm{C}$ (Filpișu Mare station) (Tab.2)

In agreement with previous studies on the thermal characterization of soils in the Transylvanian Plain, based on temperatures recorded at $50 \mathrm{~cm}$ in the soil, mean annual temperature is within the range of $8^{\circ} \mathrm{C}-15^{\circ} \mathrm{C}$ specific mesic soils. (Haggard et al., 2010; Weindorf et al., 2009)

In TP during period 2009-2013, the soil moisture at $10 \mathrm{~cm}$ depth recorded a value of multiannual average $0.227 \mathrm{~m}^{3} / \mathrm{m}^{3}$, the highest value obtaining at Triteni station $\left(0.251 \mathrm{~m}^{3} / \mathrm{m}^{3}\right)$ and the lowest value at Band station $\left(0.197 \mathrm{~m}^{3}\right.$ / $\left.\mathrm{m}^{3}\right)$.

Tab. 2. Multiannual average (years 2009 - 2013) of temperature and water contentat $10 \mathrm{~cm}$ soil depth, for 8 stations in TP

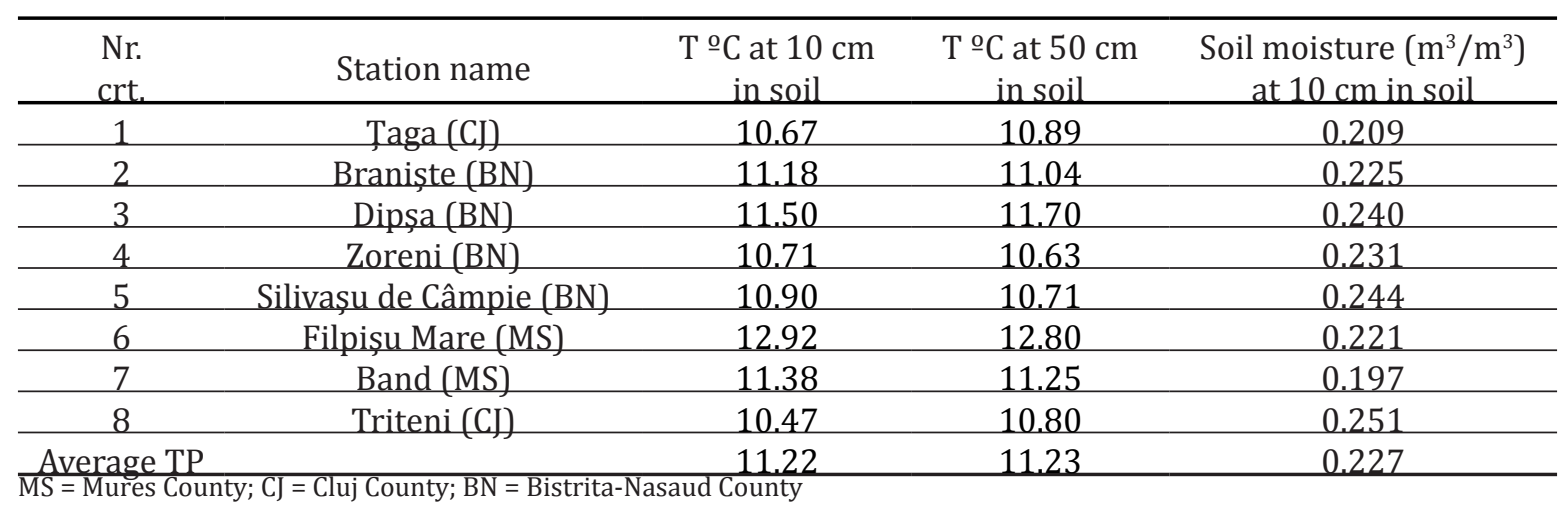


In terms of rainfall, multiannual average value recorded during 2009-2013 was 465.25 $\mathrm{mm}$ wich value is below the average annual area (500-700 mm/year). During this period there is a linear trend in their fall starting from an average annual of $503.84 \mathrm{~mm}$ in 2009 to a value of 492.8 $\mathrm{mm}$ in 2013, recording the highest value of annual average of $607.84 \mathrm{~mm}$ in 2010 and the lowest value in 2012 (345.25 mm). The year 2012 can be characterized by values of rainfall deficit for TP wich is also reflected in the low values of soil moisture $(0.202 \mathrm{~m} 3 / \mathrm{m} 3)$ for the period analyzed (Fig.1.a.).

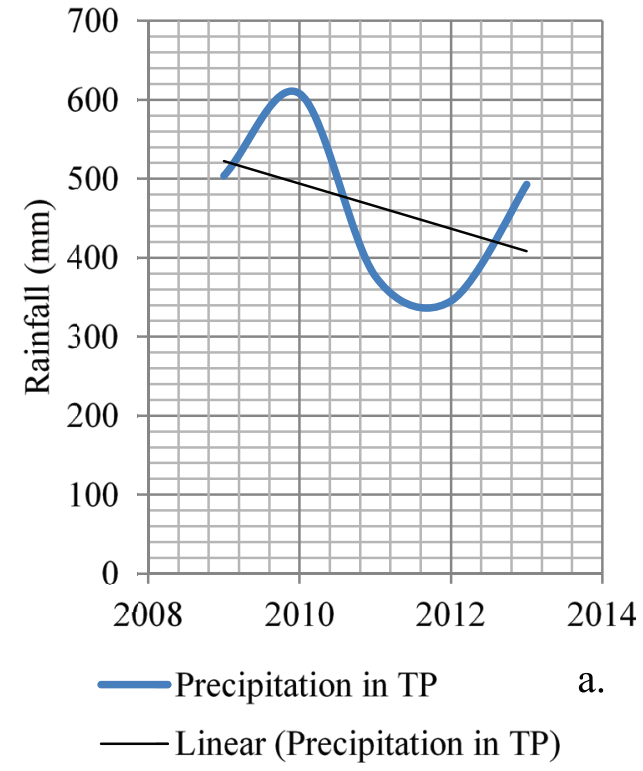

Soil moisture at $10 \mathrm{~cm}$ depth are reflected the same tendency linear decrease from a annual average of $0.245 \mathrm{~m}^{3} / \mathrm{m}^{3}$ in 2009 to a value of 0.211 $\mathrm{m}^{3} / \mathrm{m}^{3}$ in 2013 , recorded highest value of annual average $0.260 \mathrm{~m}^{3} / \mathrm{m}^{3}$ in 2010 and lowest value of annual average $0.202 \mathrm{~m}^{3} / \mathrm{m}^{3}$ in 2012 (Fig. 1.b.).

Rain factor (Lang) value were calculate for four station (Braniștea, Dipșa, Silivașu de Câmpie and Căianu) between 2009-2013 and the results indicate a Mediterranean climate at Căianu station where value of Lang factor were between 20 and 40 (35.84) and for the other stations Lang

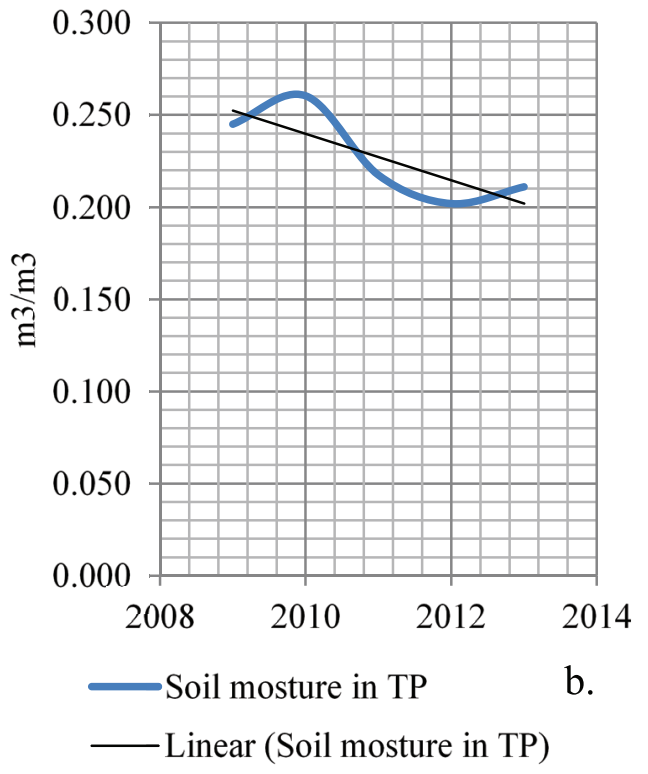

Fig.1. The evolution of the average values of rainfall $(\mathrm{mm})$ and soil moisture $(\mathrm{m} 3 / \mathrm{m} 3)$ in TP between 2009 - 2013 (a. Rainfall evolution; b. Soil moisture evolution)

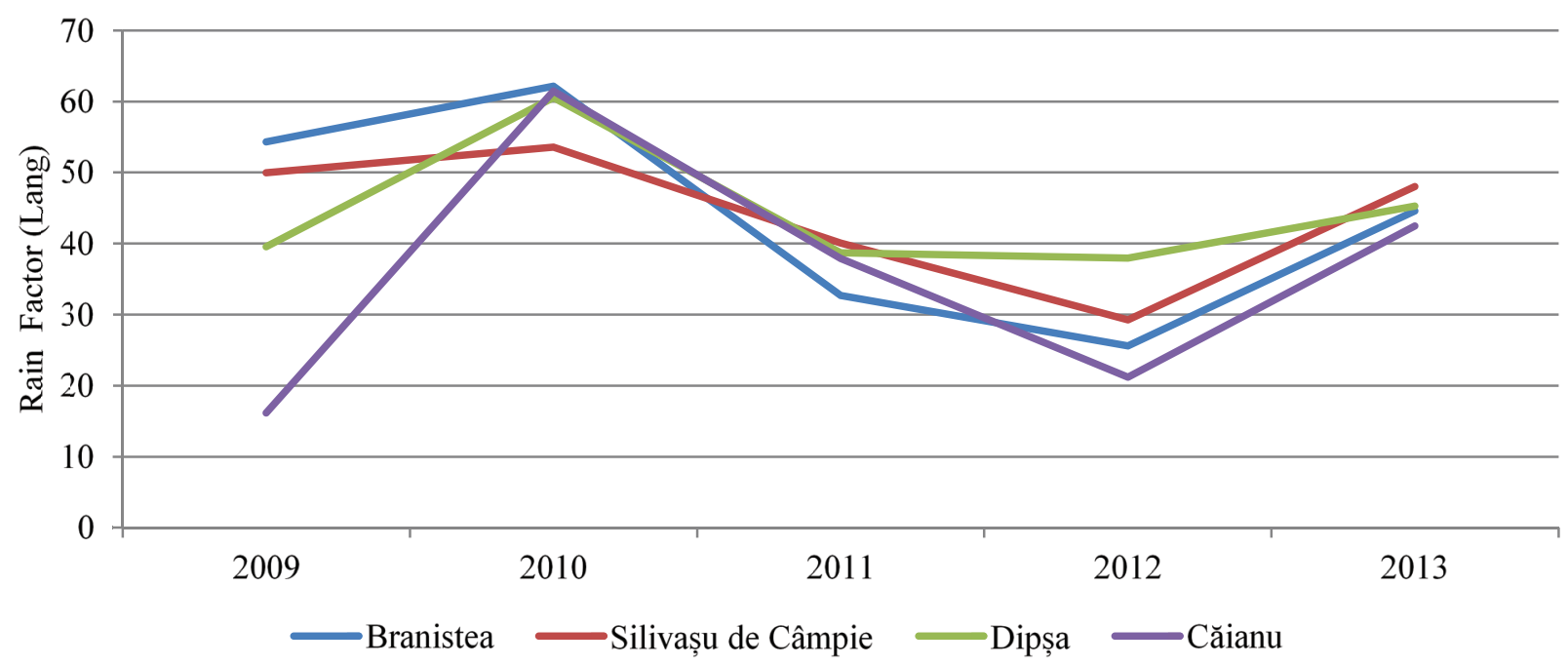

Fig. 2. Rain Factor`s evolution between 2009 - 2013 for 4 station in TP 
factor values are between 40 and 70 indicating a semiarid climate. (Fig. 2)

\section{CONCLUSION}

Different pedogenetic horizons, exhibition, gradient and vegetation covering different types of soils are factors that work together to characterize the thermal regime of the soil.

Results highlight the dynamic evolution of soil temperature at $10 \mathrm{~cm}$ and $50 \mathrm{~cm}$ depth in soil, soil moisture at $10 \mathrm{~cm}$ depth in soil, in Transylvanian Plain due to agro-climatic analysis of the indicators calculated for the period 2009 2013.

Based on the results obtained from the statistical analysis and interpretation of agroclimatic indicators one can develop specific measures to adapt to the effects of observed climate changes.

Acknowledgments. "This paper was published under the frame of European Social Found, Human Resources Development Operational Programme 2007-2013, project no. POSDRU/159/1.5/ S/132765" and was performed under the frame of the Partnership in priority domains - PNII, developed with the support of MEN-UEFISCDI, project no. PN-II-PT-PCCA-2013-4-0015: Expert System for Risk Monitoring in Agriculture and Adaptation of Conservative Agricultural Technologies to Climate Change.

\section{REFERENCES}

1. Babinszky L, Veronika Halas, Verstegen MWA (2011) Impacts of Climate Change on Animal Production and Quality of Animal Food Products, In: "Climate Change
- Socioeconomic Effects" editated by Juan Blanco and Houshang Kheradmand, ISBN 978-953-307-411-5

2. Busuioc A, Dumitrescu Al, Soare E, Orzan A (2007). Summer anomalies in 2007 in the context of extremely hot and dry summers in Romania. Romanian Journal of Meteorology, Vol. 9, No. 1-2, ISSN 1223-1118

3. Busuioc A, Dobrinescu A, Birsan MV, Dumitrescu A, Orzan A (2014). Spatioal and temporal variability of climate extremes in Romania and associated large-scale mechanisms. International Journal of Climatology. Published online in Wiley Online Library (wileyonlinelibrary.com) DOI: 10.1002/joc.4054

4. Climate change, impacts and vulnerability in Europe (2012). An indicator - based report, Summary, European Environment Agency, ISBN 978-92-9213-346-7, ISSN 1725-9177, doi:10.2800/66071

5. Haggard B, Rusu T, Weindorf D, Cacovean H, Moraru P, Sopterean M (2010). Spatial soil temperature and moisture monitoring across the Transylvanian Plain in Romania. Bulletin UASVM Agriculture, 67(1):130-137.

6. Lereboullet AL, Beltrando G, Bardsley DK (2013). Socioecological adaptation to climate change: A comparative case study from the Mediterranean wine industry in France and Australia. Agriculture, Ecosystems \& Environment Vol. 164:273-285.

7. Rusu T, Sopterean ML, Moraru PI, Bogdan I, Pop AI, Cîmpean P (2012). Climate Monitoring and Water Resources Management for Agricultural Production in the Transylvanian Plain, Romania. Bulletin UASVM, series Agriculture 69(1-2):297-299

8. Rusu T, Moraru PI, Bogdan I, Pop AI, Cacovean H (2013). Impacts of climate change on agricultural technology management in the Transylvanian Plain, Romania. Geophysical Research Abstracts Vol. 15, EGU2013-5770

9. Van Den Hurk B, Hirski M, Schär C, Lenderink G, Van Meijgaard E, Van Ulden A, Rockel B, Hagemann S, Graham P, Kjellström E, Jones R (2005). Soil control on runoff response to climate change in regional climate model simulations. Journal of Climate, 18: 3536-3551

10. Weindorf, D., Haggard B, Rusu T, Cacovean H, Johnson S (2009). Soil Temperatures of the Transylvanian Plain, Romania. Bulletin UASVM, Agriculture, 66(1):237-242 